DOI https://doi.org/10.18551/rjoas.2018-01.20

\title{
THE EFFECT OF MACROECONOMIC VARIABLES ON BANKING STOCK PRICE INDEX IN INDONESIA STOCK EXCHANGE
}

\author{
Laduna Rudi, Sun'an Muammil* \\ Faculty of Economics, University of Ternate, Indonesia \\ *E-mail: amilsunan78@gmail.com
}

\begin{abstract}
Stock price index can be regarded as a barometer in the measuremet of a nation's economic condition, besides it can also be used in conducting statistical analysis on the current market. Stock is the proof of one's share in a company in the form of securities issued by the listed go-public companies. This study was conducted to measure the effect of macroeconomic variables such as inflation, interest rate, and exchange rate on banking stock price index in Indonesia stock exchange or Bursa Efek Indonesia (BEI). The results of study show that inflation and exchange rate posively influence the stock price index. The positive effect of the exchange rate shows that issuers who were positively affected by Rupiah (IDR) depreciation appear to be the most dominant group. Meanwhile, the interest rate or Suku Bunga (SBI) has a negative effect. Lower interest rate stimulates higher investments and better economic activities which increase the stock price.
\end{abstract}

\section{KEY WORDS}

Inflation, exchange rate, interest rate, banking, stock price index.

Capital market plays a crucial role for a nation's economy since it runs two major functions; to provide business funding and to facilitate companies with investment from investors. Capital market cannot be separated from stock price index. Current amount of composite share price index or Indeks Harga Saham Gabungan (IHSG) has always been updated and displayed in electronic mass media or non-electronic mass media everyday.

Moradoglu, et al. (2000) stated that there have studies conducted on stock price behavior, especially related to its relationship with macroeconomic variables such as the ones conducted by Chen et al. (1986), and Fama (1981). Their studies show that stock price is influenced by fluctuation that occurs in macroeconomic variables. Their studies involved some macro-economic variables including; inflation rate, interest rate, exchange rate, industrial production index, and oil price. A number of studies have confirmed the effect of inflation rate toward stock returns such as the one conducted by Balduzzi (1994), Sitorus (2004), Schmeling and Schrimpf (2008). Interest rate that goes higher than the expected return makes investors choose deposits for their investment. In their studies, Lee (1992) and Gan et al (2006) have proven that interest rate has a significant influence toward stock price index.

Fabozzi and Franco (1996:724) mentioned that an exchange rate is defined as the amount of one currency that can be exchange per unit of another currency, or the price of one currency in items of another currency. Similarly, Ajayi and Mougoue (1996) also used macro-economic variables which were exchange rate and stock price in their studies. Their studies indicate a dynamic correlation between stock price and exchange rate in the top eight leading countries in capital market including Canada, France, Germany, Italia, Japan, Netherland, England and The United States based on the result of a measurement using bivariate error correction model. The results of those studies show a significant correlation between exchange rate and stock price (capital market and money market). Some other studies also support this view such as Dimitrova (2005), Sudjono (2002) and Sitinjak dan Kurniasari (2003) in which it is stated that rupiah exchange rate significantly influences the IHSG.

A contradictory result is shown by Gupta (2000) who conducted a study on the issue that occurred in Indonesia from 1993-1997 which concludes that there is no causal-effect 
relationship between interest rate, exchange rate and stock price. This result is supported by the one found by Budilaksono (2005). However, a study conducted by Sitinjak and Kurniasari (2003) shows that exchange rate and interest rate have significant effects toward the IHSG. Yet, Saadah and Panjaitan (2006) did not find any dynamic or significant interaction between stock price and exchange rate.

The fact that previous studies show some debatable results upon the factors that influence IHSG has triggered researcher's curiosity in understanding "The Effects of Exchange Rate, Inflation Rate and Interest Rate toward Bank Stock Price Index in Indonesia Stock Exchage or Bursa Efek Indonesia (BEI) in 2010-2016".

\section{LITERATURE REVIEW}

Stock is defined as legal document that shows one's ownership upon a company (Fakhruddin and Hadianto, 2001: 6), and securities that show one's ownership upon a company that opens its stock (Darmadji and Fakhruddin, 2001: 5).

Based on the ownership, stock can be grouped into 2 types (Fakhruddin and Hadianto, 2001: 2012) which are:

Common stocks. Common stocks are stocks owned by junior investors who receive the lowest dividend and assests if the company were liquidated. Common stocks are the most common securities sold in the capital market. Stockholders of common stocks also possess these following rights:

Rights to Control - Stockholders have the right to vote for Board of Directors. This means that they are able to control anyone who are leading the company. Stockholders may use their right to control by issuing veto during the election of the Board of Directors in annual meeting of shareholders.

Rights to Receive Dividend - As owners of a company, stockholders receive profit from the earning of the company. A company would use most of the earnings to be invested back for the company and share a part of the profit to the stakeholders. This investment is called retained earning which is an intern source of fund. The unretained earnings are the ones that are shared to the stackeholders in the form of dividend.

Preemtive Right. Preemtive right is the right to have equal ownership if a company relases additional shares. When a company releases additional shares, the number of shares in the market is increased. As the result, the percentage of current stocks ownership is decreased. Preemtive right gives a priority for old stockholders to buy the additional shares in oder to maintain the percentage of their ownership upon the company.

Preferred Stocks. Preferred stock is a combination between common stocks and debenture for it gives a fixed earning and dividend as expected by the investor. Preffered stocks are similar to common stocks since they reflect holders' ownership of a company equity, they are released without due date, and they require the company to pay dividend. Preferred stocks differ form debenture in three aspects; claim upon company profit and assests, fixed amount of dividend before the due data, redemption rights and they can be exchanged with common stocks.

The Correlation between Exhange Rate and Stock Returns. Theoretically, there are two perspectives upon the relationship between stock price and exchange rate. In one side, those who support the 'portfolio-balance' view believe that stock price negatively influences exchange rate (Saini et al., 2002). Company's equity which is a part of company's wealth has certain influence toward exchange rate through money demand. For example, the higher the stock price, the higher the demand for money and the higher the interest rate that apply. This condition attracts foreign investros to make investment which results to appreaciation of domestic currency.

Furthermore, stock price also influences the exchange rate through money demand equation that forms a basic model of portfolio allocation and monetary policies as the result of the determination of currecy exchange rate. In certain condition that precisely reflects real economic activities, changes upon stock price cause increase in money demand and increased values of domestic currency (Ajayi, Ibrahim, 2000). Solnik (in Ibrahim, 2000) stated 
that stock price reflects macro-economic variables since it shows market expectation upon real economic activities. This model proposes currency exchange rate, in which any fluctuation of stock price might trigger some effects to the exchange rate. Solnik (in Ibrahim, 2000) also found a weak positive correlation between differences in stock returns (domestic minus foreign) and the changes of riil exchange rate. Mok (1993) has confirmed that exchange rate (FOREX) and stock price appear to be two independent variables. However, there is a two-way causal relationship between FOREX and closing as well as opening stock price. Exchange rate also influences the stock price, yet the growth of capital market also pushes the positive effect of the exchange rate.

The Correlation between Interest Rate and Stock Returns. Interest rate is the price of the loaned fund (Reilly and Brown, 1997). A company's plan to fulfill capital needs is highly influenced by the current rate of interest. Based on the interest rate, a company would determine either to release equity securities or loan/debenture. Debenture can be done if the current rate of interest is lower than the earning power of the capital addition (Riyanto, 1990). Lower interest rate decrases the loan fee. Low interest rate also attracts more investment and economic activities which eventually increase the stock price. In the context of property business, interest rate has a significant function in increasing transactions which results stronger influence toward a property business and gives direct influence to the increasing amount of stock returns. Interest rate also has a significant influence toward the stock price as stated by Granger (in Mok, 1993) that interest rate negatively affects the stock price. In line with the statement, Boedie et al (1995) also wrote that stock price is affected by some factors, one of which is the interest rate. This belief is also supported by Utami and Rahayu (2003), whose research result shows empirical proofs upon the effect of interest rate on stock price during economic crisis in Indonesia.

The Correlation between Inflation and Stock Returns. Results of previous research indicate a negative correlation between inflation rate and stock returns. Inflation is an aggregate price change. Studies on the correlation between inflation rate and stock returns have been frequently administered, especially in developing countries. Most of the studies indicate a negative correlation between inflation and stock returns.

Balduzzi (1995) observed the correlation between inflation and stock returns during January $1954-1976$ and 1977 - 1990 which result shows that inflation has a negative influence toward stock returns. A relatively similar result was confimed by Porter and Null (2007) in which it is found that inflation has a negative influence toward stock returns. Proter and Null found out a negative influence of real stock returns and inflation. When inflation is decomposed into expected and unexpected elements, real stock returns and expected inflation share a negative correlation.

Research Framework. Investors in Indonesia Stock Exhange have interests in the fluctuation of the composite share price index or Index Harga Saham Gabungan (IHSG) since the values of the stock portfolio highly depend on this index. Most stocks or stock portfolio moves in line with the index movement. Frensidy (2009) stated that stock price is highly influenced by macro variables such as risk-free interest rate, currency exchange rate, surplus of trade balance, foreign exchange reserve, and inflation.

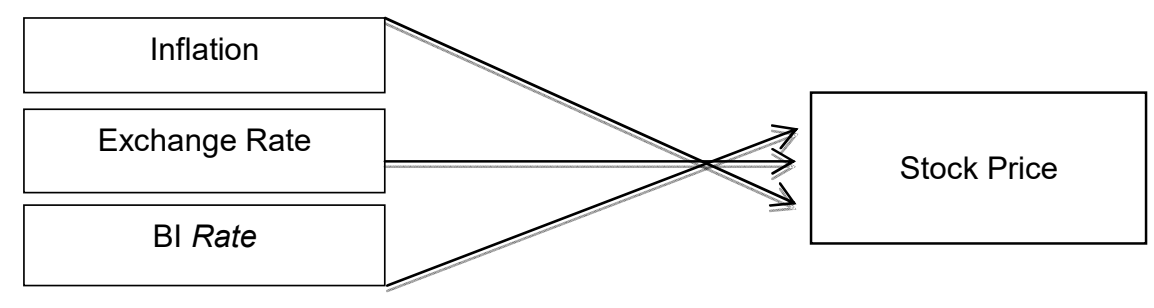

Figure 1 - Research Framework Used in this Study

Macro-economic variables in a country might influence the condition of the capital market. Setyawan (2009) mentioned that changes of exchange rate negatively affect the 
movement of IHSG. Liu \& Shrestha (2008) found a negative correlation between exchange rate index of domestic currencies in China, RMB, and stock price. Long-Term Interest Rate in China has a negative correlation to the stock price. Martini (2009) claimed that inflation and interest rate do not have any significant influence toward IHSG. Mok (1993) in Suyanto (2007) also did not find any significant correlation of interest rate and exchange rate toward stock price.

\section{METHODS OF RESEARCH}

Types and Source of the Data. Data related to inflation rate, exchange rate, interest rate and stock price index in Indonesia Stock Exchange from the time series data (monthly), from Januari 2010 to December 2015 were collected from secondary source such as reports from Indonesia Stock Exchange, financial statistics, Bank of Indonesia, etc.

Data Collection Method. The data were collected using documentary method in which the researcher collected some documents in the form of financial reports, monthly $B E I$ statistics, reports of the development of BI, Central Bureau of Statistics or Badan Pusat Statistik (BPS) and other data from books or publication related to this issue which added up some objective information through websites.

Data Analysis Method. Regression data analysis method was used to analyze the data of this study. The basic regression analysis model of this study is following:

$$
Y_{t}=\beta_{0}+\beta_{1} X 1_{t}+\beta 2 X 2_{t}+\beta 3 X 3_{t}+\mu i
$$

Where: $Y t=$ Banking Stock Price Index; $X 1=$ Inflation; $X 2=$ Exchange rate of IDR to USD; $X 3=B I$ rate; $\beta 1 \ldots \beta 3=$ Coefficient of the independent variables; $\mu=$ error.

\section{RESULTS AND DISCUSSION}

The Estimated Linear Regression Model. Regarding to the reserach problems and the objectives of this study, the resreacher employed a multiple linear regression model. The regression statistic measurement has resulted in equation of banking stock price as follows:

$$
Y=476043.703+173.337_{x 1}+0.61 x_{x 2}-1211.768_{x 3}+\varepsilon t
$$

Where: $Y=$ Banking Stock Price Index; $X_{1}=$ Inflation Rate; $X_{2}=$ Exchange Rate; $X_{3}=$ Interest Rate $\left(B /\right.$ rate); $\beta_{0}=476043.703$, if the inflation rate, exchange rate and interest rate are assumed constant (ceteris paribus), then the banking stock rate price is at 476043.703 ; $\beta_{1}=173.337$, if there is $1 \%$ increase in the inflation rate while the exchange rate and interest rate remain constant (ceteris paribus), then the stock price will increase as much as 173,337; $\beta_{2}=0.612$, if there is $1 \%$ incrase in the currency exchange rate, while the inflaion rate and interest rate remain constant (ceteris paribus), the stock price will incrase as much as $0.612 \% ; \beta_{3}=1211,768$, if there is $1 \%$ increase in interest rate of $S B I$, while inflation rate and exchange rate remain constant (ceteris paribus), the stock price will decrease as much as 1211,768 .

\begin{tabular}{|c|c|c|c|c|c|c|}
\hline \multicolumn{7}{|c|}{ Coefficients $^{a}$} \\
\hline & \multirow{2}{*}{ Model } & \multicolumn{2}{|c|}{ Unstandardized Coefficients } & \multirow{2}{*}{$\begin{array}{c}\text { Standardized Coefficients } \\
\text { Beta }\end{array}$} & \multirow[b]{2}{*}{$\mathrm{t}$} & \multirow{2}{*}{ Sig. } \\
\hline & & $\mathrm{B}$ & Std. Error & & & \\
\hline \multirow{4}{*}{1} & (Constant) & 476043.703 & 103506.043 & & 4.599 & .000 \\
\hline & Inflation & 173337 & 70.453 & 302 & 2460 & 016 \\
\hline & Exchange & .612 & .128 & .700 & 4.790 & .000 \\
\hline & SBI & -1211.768 & 222.541 & -.843 & -5.445 & .000 \\
\hline
\end{tabular}

Table 1 - The Result of Multiple Linear Regression Test

Source: Data Analysis (2017). 
A partial measurement of the regression coefficient tests the correlation among research variables in a separated way. The effect of each independent variable is partially reflected by the value of each t-statistic.

Partial Test. Partial test was done to see the effect of each independent variable (inflation rate, exchange rate, and $B /$ rate) on the dependent variable (banking stock price index). If the $p$-value < significant level of $5 \%$, it can be concluded that there is a significant effect of each independent variable on the dependent variable. Based on the result of the statistic measurement in this study, inflation has been known to have a positive effect to the banking stock price index during 2010-2015. The regression coefficient of the inflation is found at a positive orientation 173.337 and the t-statistics is found at 2.460 with probability value of 0.01 . The significance value is lesser than the level of significance $(0.01<0.05)$ which indicates that inflation has a positive and significant correlation to the banking stock price index in BEI in 2010-2015. This result accepts the first hypothesis of this study.

. Meanwhile, the exchange rate of IDR to USD has been found to have a positive correlation with banking stock price index in 2010-2015. Based on the result of the measurement, the regression coefficient of the exchange rate is at a positive orientation at 0.612 and t-statistic at 4.790 with probability value of 0.00 . The significance value is lesser than the level of significance $(0.00<0.05)$ which means that exchange rate has a positive and significant influence towad the banking stock price in BEI during $2010-2015$. Hence, the second hypothesis of this study is accepted.

Furthermore, the interest rate $(B I$ rate) has been found to have a negative influence toward the banking stock price index in $2010-2015$. The result of the measurement shows that the regression coefficient of the exchange rate is at a negative orientation -1211.768 and the t-statistic is 5.445 with probability value of 0.00 . The significance value is lesser than the level of significance $(0.00<0.05)$ which indicates that interest rate has a negative and significant influence toward the banking stock price index in BEI in $2010-2015$. Therefore, the second hypothesis of this study is accepted.

Simultaneous Test. Simultaneous test was administered to see the simultaneous influence of the independent variables toward the dependent variable. In this study, $F$ test was used to measure the simultaneous influence, in which if the prob $F<$ level of significance $5 \%$, the independent variables simultaneosly have a significant influence toward the dependent variable.

It can be seen in Table 9 that the independent variables simultaneosly have a significant influence toward the dependent variable. This relationship is proven by the probability value at 0.00 . Therefore, the fourth hypothesis of this study is accepted.

Table 2 - The Result of Simultaneous Regression Test

\begin{tabular}{|c|c|c|c|c|c|c|}
\hline \multicolumn{7}{|c|}{$\mathrm{ANOVA}^{\mathrm{a}}$} \\
\hline & Model & Sum of Squares & $\mathrm{df}$ & Mean Square & $\mathrm{F}$ & Sig. \\
\hline \multirow{3}{*}{1} & Regression & 259525833813.947 & 3 & 86508611271.316 & 11.908 & $.000^{b}$ \\
\hline & Residual & 493989110201.554 & 68 & 7264545738.258 & & \\
\hline & Total & 753514944015.500 & 71 & & & \\
\hline
\end{tabular}

Test of Classic Assumption. The result of Durbin-Watson test shows DW-statistic value of 1.447. compared to the table at $5 \%$ significance level, $n-k-1, \mathrm{dL}$ is obtained at 1.50 and $\mathrm{dU}=0.123$ between the $\mathrm{dL}$ and $\mathrm{dU}(\mathrm{dL}<\mathrm{d}<\mathrm{dU}$. It means that the non-autocorrelation test cannot be drawn into conclusion. Yet, the Durbin-Watson values obtained in this study were between -2 and +2 which indicate that the regression model contains no sign of autocorrelation.

Multi-collinearity appears when one or more independent variables have strong correlation toward other independent variables. Multi-collinearity can be measured from (1) tolerance value and it's opposite (1) variance inflation factor (VIF). The two measurements show which independent variable is being explained by other independent variable. 
Regarding to the correlation values among the independent variables, it is known that no variable has a relatively significant correlation to the independent variable. The result of tolerance test also shows that there is no independent variable with tolerance value lesser than $10 \%$, which indicates no correlation between independent variables which tolerance values are greater than $95 \%$. In addition, VIF value also shows similar result in which there is no independent variable with VIF value greater than 10 . Therefore, it can be concluded that multi-collinearity does not exist among the independent variables used in this regression model.

The Effect of Inflation toward Banking Stock Price Index. The test shows regression coefficient of inflation is positively oriented at 173.337 with 0.01 probabilities. The significance value is lesser than the significance level $(0.01<0.05)$ which means that inflation has a positive and significant influence on the banking stock price index of BEI during 20102016.

The positive coefficient value shows that $1 \%$ increase in inflation will be followed by increase in the banking stock price index as much as $0.06 \%$. The result of this study supports the result of a study conducted by Wijaya Kusuma (2010). In his research, it is stated that inflation has a negative and significant influence on the banking stock price index in $\mathrm{BEI}$.

According to researcher's explanation, the type of inflation might make some differences since demand-pull inflation occurred when the study was being conducted. Demand-pull inflation occurs as the result of increase in the total demand which not only it increases the price, but it also increases the production (output) (Nopirin, 2011). Companies increase their production and the price to get more profit because the demand is higher.

The Effect of Exchange Rate toward Banking Stock Price Index. Solnik (in Ibrahim, 2000) stated that stock price reflects macro-economic variables since it also shows market expectation of the real economic activities. Since the currency exchange rate, such as in the monetary context, correlates with other macro-economic variables, then any change in stock price might influence the exchange rate. Solnik (in Ibrahim, 2000) also found a positive yet weak correlation between stock returns (domestic minus foreign) and fluctuation of the real exchange rate. The test showed the regression coefficient of the exchange rate at the positive orientation 0.612 with 0.00 probabilities. The significance value is lesser than the level of significance $(0.00<0.05)$ which indicates that exchange rate has a positive and significant influence on the banking stock price index in BEI during 2010-2015.

Coeffients with positive values show that $1 \%$ depreciation of IDR to USD will be followed by 0.612 increases in the banking stock price index. This result goes in line with the one conducted by Alpan Wijaya Kusuma (2010) which states that exchange rate significantly influences the IHSG. Exchange rate that has a positive influence shows that the most dominant issuer group is the one that obtain positive effects of IDR depreciation. IDR depreciation motivates companies that focus on running export business to increase their export volume. Most of the companies use local materials but they sell it in foreign currencies which give the companies higher profit.

The Effect of Interest Rate toward Banking Stock Price Index. Low interest rate causes creates lower loan fee. Lower interest rate also attracts more investment and more active economic activities which eventually increase the stock price. In property business, interest rate has a key role in improving transaction which strongly influences the performance of a property company and directly influences the increase in stock returns. It is stated by Granger (in Mok, 1993) that interest rate negatively affects the stock price.

The test has resulted a regression coefficient of $B /$ rate in the negative orientation at 1211.768 with 0.00 probability value. The significance value is lesser than the level of significance $(0.00<0.05)$ which means that $B /$ rate has a negative and significant influence on the banking stock price index in BEI during 2010-2016.

Negative coeffient indicates that $1 \%$ increase in $B /$ rate will be followed by 1211.768 decrease in the banking stock price index. This result supports Etty Murwaningsari (2008) which found that $B /$ rate or interest rate has negative significant influence on IHSG. When the interest rate is high, invidiuals tend to make saving or deposit their money to get higher 
returns. In another word, when the interest rate is low, people tend to buy more securities in their portfolio (Nopirin, 2000). Increase in B/ rate drives investors to make saving and deposit their money which cause weak investment and eventually decrease the IHSG.

\section{CONCLUSION AND SUGGESTIONS}

Regarding to the result of the data analysis and the discussion of this study presented in chapter IV, conclusions are drawn as follow:

Inflation positively influences IHSG. In this study, demand-pull inflation occurred because of the increase in the total demand. This type of inflation does not only cause the price to increase but it also increases the output that eventually increase the profit obtained by a company. The increase in output can be seen from the gross domestic product (GDP) that keeps increasing each year. Higher amount of output is a good condition to enhance the investment.

Exchange rate positively influences IHSG. Exchange rate that has a positive influence shows that the most dominant issuers are those who receive benefits from IDR depreciation. Depreciation of local currency stimulates exporters to increase their export volumes. Export companies produce their products using local materials which later are sold in foreign currency for higher profit.

$B I$ rate negatively influences IHSG. Increase in $B /$ rate is a potential trigger that drives investors to save more or to deposite their money which decrease the amount of investment in the capital market. In another word, lower interest motivates investors to buy more securities in their portfolios. as follow:

Regarding to the conclusions and limitations of this study, some suggestions are made

Investors are recommended to pay more attention to macro-economic variables and stock trading volume before taking any decision related to their investment. Those information have been proven to have some influences toward the composite stock in BEI both simultaneosly or partially. Therefore, that information should be taken into account in making any consideration to predict the IHSG before deciding to make any investment.

Investors should also regard any additional information to enrich their references in making decision related to their investment because there are some other factors that influence the movement of the stock price index aside from the ones that have been explained in this study.

Government should be wise in controlling the macro-economic conditions to keep the national economy good and stable. Thus, the investment can be enhanced.

\section{REFERENCES}

1. Case, K.E. \& Fair R.C. (1999), Principle of Economics, 5th Edition, Prentice Hall International, Inc., New Jersey.

2. Chen, N.F., R.Roll \& S.Ross (1986). Economic Forces and the Stock Market. Journal of Business, Vol.59, pp.383-403.

3. Dimitrova, Desislava. 2005. The Relationship between Exchange Rate and Stock Price : Studied in A Multivariate Model. Issues in Political Economy, Vol. 14.

4. Fabozzi, E.J. \& Francis, J.C. 1996. Capital Markets and Institution and Instrument. Upper Saddle River New Jersey.

5. Fama, E.F. \& K.R. French. 1992. The Cross Section of Expected Stock Returns. Journal of Finance. 47:427-465.

6. Gan, Christopher, Minsoo Lee, Hua Hwa Au Yong, \& Jun Zhang. 2006. Macroeconomic Variables and Stock Market Interactions: New Zealand Evidence, Investment Management and Financial Innovations, Vol. 3, Issues 4, 2006: 89-101.

7. Gupta, Jyoti P., Alain Chevalier \& Fran Sayekt. 2000. The Causality between Interest Rate, Exchange Rate and Stock Price in Emerging Market: The Case of the Jakarta Stock Exchange. Working Paper Series. EFMA 2000.Athens. 
8. Habib Lotfi, Reza Moshari \& Mortaza Lotfi. 2009. Pengaruh Variabel Ekonomi Makro Terhadap Indeks Harga Total Bursa Saham di Teheran, Iran. The International Conference on Islamic Economics and Economies of the OIC Countries, 28 - 29 April 2009.

9. Lee, SB. 1992. Causal Relations among Stock Return, Interest Rate, Real Activity, and Inflation. Journal of Finance, 47:1591-1603.

10. Mankiw, N Gregory. 2006. Principles of Economics. Penerjemah: Chriswan Sungkono. Jakarta: Salemba Empat.

11. Samsul, M. 2006. Pasar Modal \& Manajemen Portofolio. Jakarta: Erlangga.

12. Muradoglu, G., Fatma Taskin, \& like Bigan. 2000. Causality Between Stock Returns and Macroeconomic Variables in Emerging Markets. Russian and East European Finance and Trade. 36:35-53.

13. Schmeling, Maik \& Andrew Schrimpf. 2008. Expected Inflation, Expected Stock Returns, and Money Illusion: What Can We Learn From Survey Expectation? SFB 649 Discussion Paper 2008-036.

14. Sitorus, Maurin. 2004. Pengaruh Variable Makroekonomi Terhadap Kinerja Saham Pertambangan Minyak Dan Gas Bumi Sebagai Emiten Di Bursa Efek Indonesia. www.yai.ac.id.

15. Sudjono. 2002. Analisis Keseimbangan dan Hubungan Simultan Antara Variabel Ekonomi Makro Terhadap Indeks Harga Saham di BEJ dengan Metode VAR (Vector Autoregression) dan ECM (Error Correction Model). Jurnal Riset Ekonomi dan Manajemen. Vol. 2. No. 3.

16. Setyorini \& Supriyadi. 2000. "Hubungan Dinamis Antara Nilai Tukar Rupiah dan Harga Saham di Bursa Efek Jakarta Pasca Penerapan Sistem devisa Bebas Mengambang". Simposium Akuntansi Nasional.Ke-III. Hal 771-793.

17. Tirapat, Sunti, \& Aekkachai Nittayagasetwat., 1999, "An Investigation of Thai Listed Firms's Financial Distress Using Macro and Micro Variables", Multi National Finance Journal.Jun 1999; 3, 2, pp.103-118. 